\title{
Initial surveillance of suspected undesirable drug reactions to some Artemisinin-based combination therapies (ACTs) in Lagos, Nigeria
}

\author{
Bamgboye M Afolabi ${ }^{*}$, Antonia Dunkwu², A C Oparah ${ }^{3}$ \\ From Parasite to Prevention: Advances in the understanding of malaria \\ Edinburgh, UK. 20-22 October 2010
}

\section{Background}

The exacerbation of malaria in sub-Saharan Africa towards the end of the 20th century accrued from amplified resistance to chloroquine and sulfadoxine-pyrimethamine (SP) the most affordable antimalaria medicines [1]. Contact with substandard antimalarial medicines probably aggravated this development [2-4].
Pressure from malaria scientists triggered extensive acceptance and implementation of artemisinin-based combination therapies (ACTs) by endemic country governments and donors [5]. All medicines carry some risk of harm and it is important to monitor their intended and unwanted effects for good evidence upon which to base an assessment of risk versus effectiveness or risk

Table 1 Proportion of patients with suspected adverse drug reactions (SADRs) to various Artemisinin-based combination therapies (ACT) in Lagos (2008).

\begin{tabular}{|c|c|c|c|c|c|}
\hline SADRs & $\begin{array}{c}\text { Artemisinin } \\
\begin{array}{c}\text { Monotherapy (number } \\
\text { of reports }=410 \text { ) }\end{array}\end{array}$ & $\begin{array}{l}\text { Artesunate-Mefloquine } \\
\text { (number of } \\
\text { reports }=521 \text { ) }\end{array}$ & $\begin{array}{c}\text { Artesunate- } \\
\text { Amodiaquine (number } \\
\text { of reports=961) }\end{array}$ & $\begin{array}{c}\text { Artemeter- } \\
\text { Lumefantrine (number } \\
\text { of reports }=401 \text { ) }\end{array}$ & $\begin{array}{c}\text { Dihydro artemisinin/SP } \\
\text { (number of } \\
\text { reports=642) }\end{array}$ \\
\hline Anorexia & 19 & 25 & 52 & 14 & 33 \\
\hline $\begin{array}{l}\text { Tightening } \\
\text { of chest }\end{array}$ & 7 & 17 & 26 & 13 & 9 \\
\hline Rashes & 10 & 21 & 28 & 20 & 55 \\
\hline Pruritis & 6 & 22 & 39 & 16 & 28 \\
\hline Dizziness & 33 & 48 & 93 & 32 & 39 \\
\hline Restlessness & 35 & 35 & 79 & 24 & 29 \\
\hline Headache & 39 & 31 & 51 & 25 & 37 \\
\hline $\begin{array}{l}\text { General } \\
\text { body pain }\end{array}$ & 19 & 24 & 43 & 16 & 18 \\
\hline $\begin{array}{l}\text { Weakness/ } \\
\text { fatigue }\end{array}$ & 43 & 47 & 102 & 32 & 46 \\
\hline Vomiting & 5 & 11 & 15 & 5 & 20 \\
\hline $\begin{array}{l}\text { Abdominal } \\
\text { discomfort }\end{array}$ & 37 & 25 & 52 & 30 & 32 \\
\hline Insomnia & 17 & 21 & 46 & 13 & 29 \\
\hline $\begin{array}{l}\text { Swollen/ } \\
\text { blistered lips }\end{array}$ & 9 & 6 & 10 & 11 & 46 \\
\hline Hallucination & 3 & 17 & 16 & 9 & 14 \\
\hline
\end{tabular}

'Health, Environment and Development Foundation, 34 Montgomery Road,

Yaba, Lagos, Nigeria

Full list of author information is available at the end of the article

(c) 2010 Afolabi et al; licensee BioMed Central Ltd. This is an open access article distributed under the terms of the Creative Commons 
versus benefit. Furthermore, particularly with new medicines, the early identification of unexpected adverse reactions and their risk factors is essential, so that the medicines can be used in an informed manner with the least chance of harm. This is the role of pharmacovigilance (PV). Information gathered during pharmacovigilance may also assist in selecting the most appropriate medicine for future use. The objectives of this study were to document the suspected undesirable but common adverse drug reactions (SADRs) of patients using various Artemisinin-based Combination therapies (ACTs) in Lagos, (Nigeria) and to document the involvement of community pharmacists in the detection and reporting of these ADRs.

\section{Materials and methods}

A semi-structured questionnaire was served to each of the 235 randomly selected community pharmacists/ respondents in urban and semi-urban Lagos metropolis between May and July 2008 out of which 201 (83.8\%) responded.

\section{Results}

Nine hundred and sixty one reports of SADR to Artesunate-Amodiaquine (AA) combination were reported followed by 642 to dihydro-artemisinin-SP combination, 521 to Artesunate-Mefloquine combination, 401 to Artemisinin monotherapies and 401 to ArtemeterLumefantrin combination (Table 1). When Artesunate Amodiaquine was compared with Artemeter Lumefantrin, there were significant differences in the proportion of patients with weakness and fatigue $(102,37.8 \%$; 32, 11.9\%; OR 4.52; $\mathrm{p}<0.0001)$, dizziness (93, 38.0\%; 32, $12.1 \%$; OR 4.07; $\mathrm{p}<0.0001)$, headache $(51,27.9 \%$; 25 , 13.7\%; OR 2.44; $\mathrm{p}<0.0001)$, insomnia $(46,36.5 \%$; 13 , 10.3\%; OR 5.00; $\mathrm{p}<0.0001$ ), abdominal discomfort (52, $28.5 \%$; 30, 17.0\%; OR 1.6; $\mathrm{p}<0.05)$ and depression $(14$, $44.1 \%$; 3, 8.8\%; OR 8.16; $\mathrm{p}<0.0001)$.

\section{Conclusions}

Suspected adverse drug reactions especially to AA are factors that limit its use as an effective ACT which has unpalatable reactions to the patient. The confidence of end users of this particular ACT wanes with the development of suspected but constant mild, moderate to severe adverse drug reactions.

\section{Author details}

${ }^{1}$ Health, Environment and Development Foundation, 34 Montgomery Road, Yaba, Lagos, Nigeria. ${ }^{2}$ National Agency for Food and Drugs Administration and Control, Oshodi, Lagos, Nigeria. ${ }^{3}$ Faculty of Pharmacy, University of Benin, Benin City, Edo State, Nigeria.

Published: 20 October 2010
References

1. Gomes M, Wayling S, Pang L: Interventions to improve the use of antimalarials in south-east Asia: an overview. Bull World Health Organ 1998, 76:9-19.

2. Minzi OMS, Moshi MJ, Hipolite D, Massele AY, Tomson G, et al: Evaluation of the quality of amodiaquine and sulphadoxine/pyrimethamine tablets sold by private wholesale pharmacies in Dar Es Salaam Tanzania. Journal of Clinical Pharmacy and Therapeutics 2003, 28:117-122.

3. Amin AA, Snow RW, Kokwaro GO: The quality of sulphadoxinepyrimethamine and amodiaquine products in the Kenyan retail sector. Journal of Clinical Pharmacy and Therapeutics 2005, 30:559-565.

4. Basco LK: Molecular epidemiology of malaria in Cameroon. XIX. Quality of antimalarial drugs used for self-medication. Am J Trop Med Hyg 2004, 70:245-250.

5. Attaran A, Barnes Kl, Curtis C, D'Alessandro U, Fanello Cl, et al: WHO, the Global Fund and medical malpractice in malaria treatment. The Lancet 363(9404) 2004, 237-240.

doi:10.1186/1475-2875-9-S2-P1

Cite this article as: Afolabi et al:: Initial surveillance of suspected undesirable drug reactions to some Artemisinin-based combination therapies (ACTs) in Lagos, Nigeria. Malaria Journal 2010 9(Suppl 2):P1.

\section{Submit your next manuscript to BioMed Central} and take full advantage of:

- Convenient online submission

- Thorough peer review

- No space constraints or color figure charges

- Immediate publication on acceptance

- Inclusion in PubMed, CAS, Scopus and Google Scholar

- Research which is freely available for redistribution

Submit your manuscript at www.biomedcentral.com/submit 